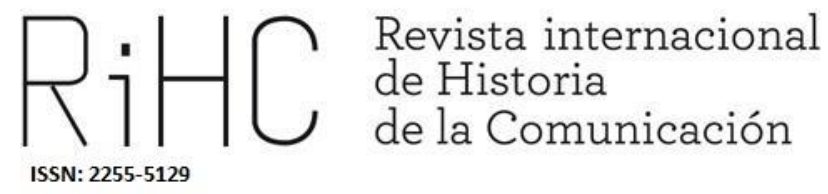

\title{
TV GLOBO E O COMÍCIO DAS DIRETAS JÁ NA PRAÇA DA SÉ EM SÃO PAULO: UM TESTEMUNHO DIRECIONADO AO ESQUECIMENTO
}

TV Globo and the Direct now rally in the Sé Square in São Paulo: a testimony directed to oblivion

DOI: http://dx.doi.org/10.12795/RiHC.2018.i11.04

Recibido: 06/10/2018

Aceptado: $15 / 11 / 2018$

Publicado: $15 / 12 / 2018$

Ana Regina Rêgo ORCID (D) https://orcid.org/0000-0002-0915-8715

Universidade Federal do Piauí-Brasil, anareginarego@gmail.com

Ranielle Leal ORCID (D) https://orcid.org/0000-0002-5563-8314

FAMECOS-PUC-RS- Brasil, Ranileal29@gmail.com

Resumo: Este artigo aborda o relacionamento entre o testemunho, a construção da memória e as raízes do esquecimento, a partir da análise e interpretação da narrativa 
de uma matéria veiculada pela Rede Globo de Televisão no dia 25 de janeiro de 1984, data em que se realizou um dos maiores comícios do movimento pelas eleições Diretas Já no Brasil, na praça da Catedral da Sé na cidade de São Paulo. Partimos da conceituação do testemunho no ambiente da filosofia para encontrarmos as possibilidades de construções da memória coletiva e histórica, e/ou confrontarmos com as construções de narrativas do esquecimento. Do ponto de vista metodológico adotamos como guia a teoria da interpretação e da ação de Paul Ricoeur, priorizando o círculo hermenêutico proposto por este autor. $O$ contexto de desenvolvimento da pesquisa situa-se no ambiente da redemocratização do Brasil em meados da década de 1980.

Palavras-chave: Diretas Já!; Ditadura civil-militar; Rede Globo de Televisão; Testemunho; Esquecimento.

Resumen: Este artículo aborda la relación entre el testimonio, la construcción de la memoria y las raíces del olvido, a partir del análisis e interpretación de la narrativa de una materia transmitida por la Red Globo de Televisión el día 25 de enero de 1984, fecha en que se realizó un de los mayores comicios del movimiento por las elecciones directas Ya en Brasil, en la plaza de la Catedral de la Sé en la ciudad de São Paulo. Partimos de la conceptualización del testimonio en el ambiente de la filosofía para encontrar las posibilidades de construcciones de la memoria colectiva e histórica, y / o confrontar con las construcciones de narrativas del olvido. Desde el punto de vista metodológico adoptamos como guía la teoría de la interpretación y de la acción de Paul Ricoeur, priorizando el círculo hermenéutico propuesto por este autor. El contexto de desarrollo de la investigación se sitúa en el ambiente de la redemocratización de Brasil a mediados de la década de 1980.

Palabras clave: Diretas Já!; Ditadura civil-militar; Rede Globo de Televisão; Testemunho; Esquecimento

\begin{abstract}
This article discusses the relationship between the testimony, the construction of memory and the roots of forgetfulness, based on the analysis and interpretation of the narrative of an article published by Rede Globo de Televisão on January 25, 1984, when a of the biggest rallies of the Direct Elections movement In Brazil, in the square of Sé Cathedral in the city of São Paulo. We start from the conceptualization of the testimony in the environment of philosophy to find the possibilities of constructions of the collective and historical memory, and / or to confront with the constructions of narratives of forgetfulness. From a methodological point of view, we adopt Paul Ricoeur's theory of interpretation and action as a guide, prioritizing the hermeneutic circle proposed by this author. The development context of the research is located in the environment of the redemocratization of Brazil in the mid1980 s.
\end{abstract}

Keywords: Direct now!; Civil-military dictatorship; Globo Television Network; A testimony; Forgetfulness. 


\section{Introdução}

O movimento denominado de Diretas Já teve início em 1983 sob a liderança do Deputado Federal Ulisses Guimarães e tinha como objetivo pressionar o Governo de João Batista Figueiredo, último dos militares a governar o Brasil, a aprovar a Emenda à Constituição e que se denominava Dante de Oliveira, em homenagem ao seu autor, e que previa a instalação de Eleições Diretas para Presidente da República logo no início do ano de 1985, assim como, o fim do Colégio Eleitoral que desde o final da década de 1960 escolhia os Presidentes militares no Brasil.

A Emenda Dante de Oliveira concorreu com a Emenda Figueiredo que previa eleições presidenciais diretas somente em 1988.

O movimento teve caráter popular e massivo e colocou no mesmo palanque políticos de siglas distintas, assim como, sindicalistas e demais trabalhadores que estavam insatisfeitos com o Regime Civil-Militar que governava o país com "mãos de ferro" desde 1964, com agressões às liberdades individuais, de expressão e de imprensa. Milhares de pessoas foram às ruas por todo o Brasil para exigir o fim da ditadura e o início de uma nova era democrática.

Na contramão, a Rede Globo de Televisão tentava silenciar o movimento, apesar das grandes concentrações de pessoas em todo o país. As práticas jornalísticas adotadas pela TV Globo objetivavam invisibilizar um movimento de grandes proporções, pois de um lado davam pouca ou nenhuma atenção, enquanto que por outro, quando inevitável, o tema, terminava vindo ao ar, as imagens e os textos minimizavam a intensidade, o tamanho e abrangência do movimento. A Globo se colocava então como testemunha de um fato histórico, mas o distorcia perante seu público objetivando silenciá-lo e leva-lo ao esquecimento. Diante deste contexto, a intenção neste artigo é revelar as formas de tentativa de silenciamento do movimento em pauta, nas narrativas audiovisuais do Jornal Nacional da TV Globo na matéria veiculada no dia 25 de janeiro de 1984, considerando, sobretudo, o uso da figura do testemunho em primeira pessoa para descredibilizar o movimento. Para tanto, nos apoiaremos em Ricoeur (2012), Todorov (2008) e Le Goff (2003) objetivando desvendar as questões concernentes ao testemunho e sua relação com a memória e o esquecimento. Este texto está distribuído em três partes integradas dialogicamente. $\mathrm{Na}$ primeira, abordamos a figura do testemunho no jornalismo, depois nos dedicamos a conceituação do testemunho e sua relação com a memória e o esquecimento e por fim, nos dedicamos ao movimento das Diretas Já com ênfase na cobertura jornalística da Rede Globo de Televisão sobre o comício da Praça da Sé. O processo metodológico é embasado no círculo hermenêutico de Paul Ricoeur (2010) e apresentado na nota que se segue. 


\section{Nota Metodológica}

Paul Ricoeur em sua obra Tempo e Narrativa lança a proposição de que " o tempo só se torna humano na medida em que está articulado de maneira narrativa; em contraposição, a narrativa é significativa na medida em que desenha as características da experiência temporal" (RICOEUR, 2010, v.1:9). Nesse estudo o autor mencionado procura aproximar as obras de Aristóteles, Poética, e Santo Agostinho, Confissões; interligando assim, linguagem e ação, a partir de dois autores, cujas obras não coincidem temporalmente, e justifica esta escolha afirmando que ambos são de grande importância para a formulação do Círculo Hermenêutico que propõe, pois, possibilitam duas entradas ao referido círculo, já que enquanto um inquire sobre a natureza do tempo sem se preocupar com a estrutura da narrativa, outro, constrói sua teoria na intriga dramática sem considerar as implicações do tempo ( RICOEUR, 2010, v. 1: 10).

O círculo entre narrativa e temporalidade em que as aporias da experiência do tempo são apresentadas e confrontadas é apresentado no primeiro volume da obra mencionada. Nesse momento o autor ao apresentar o Círculo Hermenêutico reinvidica que os paradoxos da experiência do tempo em Agostinho não devem nada a análise da intriga realizada por Aristóteles e vice-versa e é nesse contexto que o autor propõe as mímesis I, II e III como momentos formadores do círculo proposto e essenciais para compreensão do processo narrativo.

Em mímesis I, estabelece-se o estágio de uma pré-compreensão do mundo ação, uma prefiguração de suas estruturas inteligíveis, de seus recursos simbólicos e de seu caráter temporal. Já mímesis // seria o momento da configuração do mundo e que segundo Ricoeur, seria um momento de mediação entre um antes e um depois de uma configuração. Nessa fase acontece a configuração textual onde a intriga construída ganhará uma narrativa configurante em uma concordância discordante. Mímesis III, por sua vez, é o momento da refiguração a partir do olhar do leitor, como também, é o hiato de intersecção entre a ação e o mundo configurado pela ação narrativa (RICOEUR, 2010).

A primeira entrada para o Círculo Hermenêutico se dá, segundo Ricoeur (2010), pelas aporias do tempo agostiniano, para quem o tempo é muito mais interno do que cósmico, a segunda entrada por outro lado, acontece pela Poética de Aristóteles, que diferentemente do tempo de Agostinho, considera o tempo em que as intrigas acontecem de forma lógica e prioriza o tempo cosmológico. Nesse sentido o autor realiza o movimento de se apropriar das noções aristotélicas de mythos e mímesis. Sendo o primeiro considerado uma categoria da narrativa, algo como uma imitação criadora da ação humana, configurada na ação narrada. 
Paul Ricoeur não desenvolveu seus estudos sobre narrativa no ambiente comunicacional ou jornalístico, todavia estudos que procuram interligar seu pensamento ao campo da comunicação são cada vez mais frequentes.

Desse modo, pensamos com outros autores tais como BARBOSA (2006) e LEAL (2014) que o fato do campo jornalístico ter como objeto de observação e ação, o mundo social, com o qual necessita se manter em permanente contato e em observação, com vistas a configurá-lo se colocando potencialmente em mímesis II; o torna um espaço ideal para a proliferação de narrativas sociais. O jornalismo é assim, um campo de mediação entre a ação e a história narrada, que se utiliza de uma composição da intriga com vistas a tornar o mundo inteligível ao público.

Ao longo desta pesquisa estaremos interpretando as narrativas tendo como guia de observação, compreensão e interpretação o círculo hermenêutico aqui mencionado.

\section{0 testemunho no jornalismo}

"Juro dizer a verdade, somente a verdade, nada mais que a verdade"

Esse é o juramento que todos que são lançados ou chamados para depor/testemunhar em processos judiciais fazem ou pelo menos faziam, até algum tempo, jurando com a mão direita sobre a Bíblia sagrada. Esse ato simbólico compunha o ritual jurídico, sobretudo, quando o direito canônico tinha ascensão sobre a justiça e, principalmente, quando o crente temia muito mais a lei de Deus do que a dos homens.

Jurar para Deus tinha como equivalente real o dizer a verdade, poucos se arriscariam a desafiar a força divina.

Através desse singelo exemplo visualizamos que é a verdade o valor maior desejado pela sociedade e sobre o qual Nietzsche dedica grande parte de sua obra, sempre se perguntando se foi o problema do valor da verdade que se colocou para nós ou se fomos nós que nos apresentamos diante dele (NIETZSCHE, F. BM, §1) e, por que a verdade valeria mais do que o engano, porque não há uma vontade de engano (NIETZSCHE, 2005).

No âmbito do que chamamos de instituição jornalística há uma reafirmação do próprio lugar, ao qual a verdade encontra-se atrelada como valor de venda, não apenas porque dependemos dele para sobrevivência, mas porque sendo a vontade, o 
"sentimento" que nos impele para o maior valor social, a saber: a verdade; não poderia o jornalismo que se constituiu nos últimos 150 anos como um lugar de fala confiável; existir, sem que adotasse para si, um estatuto com ethos e ética comprometidos (identidade, imagem e reputação). Um estatuto construído através de um regime de verdade composto por normas éticas, formas de apuração e práticas diárias de produção da notícia. Esse composto seria necessário para constituição do jornalismo enquanto instituição de credibilidade no seio da sociedade.

É nesse contexto de constituição do jornalismo como um dos pilares do regime de historicidade (HARTOG, 2015) da modernidade, que as empresas de comunicação se constituíram ao longo do século XX. O jornal O Globo criado na década de 1920 seria a primeira empresa do conglomerado que hoje comporta várias corporações do Grupo Globo. A Rede Globo de Televisão nasceu durante a ditadura civil-militar que vigorou no Brasil entre as 1964 e 1985 e sua atuação tanto durante o regime, quanto nos períodos democráticos prima por um discurso de venda de uma pretensa "verdade" através do denominado padrão Globo de qualidade; mas as suas ações trabalham, eventualmente, no sentido de construir narrativas diferentes da realidade, com o intuído de influenciar a opinião pública. O movimento das Diretas Já ${ }^{1}$, assim como, o atual movimento das Mulheres Unidas contra Bolsonaro ${ }^{2}$, ou, mesmo na edição do Debate Lula X Collor na eleição de $1989^{3}$, constituem momentos em que a empresa se coloca como testemunha do evento com o intuito de diminuir seu tamanho e abrangência, quando não, de invisibilizá-los.

Em suma o jornalismo se apropria de uma vontade de verdade social e se investe de uma coragem de verdade conforme Foucault (2011), uma coragem que se limita entre a verdade de um parresiástico e a verdade de um técnico ${ }^{4}$, mas que se estende como construto social e quando apropriada por uma instância de produção universal de conteúdos e informações, consegue influenciar o público de forma direta e indireta.

\footnotetext{
${ }^{1}$ Este exemplo é objeto do presente artigo e será demonstrado ao longo do texto como a Rede Globo de Televisão agiu para tentar invisibilizar o movimento em seus momentos iniciais.

2 O MUCB-Movimento das Mulheres Unidas contra Bolsonaro ou \#ELENÃO ganhou corpo nas redes sociais e mobilizou milhares de mulheres e apoiadores em todo o mundo. Tanto a Rede Globo quanto outras emissoras brasileiras negligenciaram as ações prévias do movimento que nas mídias "referência" esteve completamente silenciado, ganhando projeção só na tarde do dia 29 de setembro de 2018, quando os veículos de comunicação de outros países já noticiavam o movimento e os eventos.

${ }^{3}$ A edição do debate Lula X Collor nas eleições de 1989 é apontada como um momento crucial na decisão dos eleitores brasileiros naquele pleito. A Rede Globo de Televisão omitiu trechos importantes das falas dos candidatos trabalhando a narrativa em prol do candidato Fernando Collor de Melo. A edição ganha força por possuir na raiz a credibilidade da empresa que se coloca como testemunha ocular do evento e retrabalha os discursos como verdadeiros.

${ }^{4} \mathrm{Em}$ Coragem de Verdade (2011), Foucault trabalha os quatro modos de veridição encontrados no profeta, no sábio, no técnico e na parresía, que, em suma falam de verdades pautadas no destino, ser, tékhne e éthos. A verdade do parresiástico está pautada na fala franca que se manifesta a partir de uma injunção ética, já a verdade do técnico é permeada pelas técnicas que guiam a produção de seu discurso de verdade.
} 
Nesse sentido, gostaríamos de tomar aqui o testemunho não apenas como um componente da prática jornalística inserida nos umbrais de um regime de verdade ${ }^{5}$ que the ajuda a conferir credibilidade, pois pressupõe que seus profissionais estão tanto presenciando os acontecimentos, como entrevistando e colhendo o testemunho de quem presenciou os fatos mais marcantes da humanidade. Contudo, gostaria de tomar o testemunho como o elemento de ligação entre o acontecimento e a construção da memória através do jornalismo, elemento que como dito, faz do jornalismo um dos poucos lugares de fala em que a verdade, com todasas ressalvas, concernentes à construção discursiva, ainda se mantém como um valor socialmente aceito. Sinteticamente, seria como a criação de uma condição de testemunha por excelência da realidade, como um testemunhar construído com credibilidade moral. De certa forma um inverter as posições de todo e parte, sendo que o todo do jornalismo se concretiza pelo texto testemunhal de um dado evento em determinada temporalidade, reivindicando ou não o contexto de co-presença como requisito de sua existência.

Para tanto, assumimos aqui, nessa observação, um status ampliado para o testemunho, a partir de uma proposição em que o testemunho sai da instância pessoal, seja ela um terceiro ou o próprio jornalista; para o lugar da própria instituição jornalística, assumindo assim o jornalismo, o papel de testemunha da humanidade nos últimos séculos. Queremos propor, portanto, um pensar para o campo jornalístico que transcenda as práticas em seu tempo de produção (temporalidade), para ao mesmo tempo pensar em uma temporalização da temporalidade mencionada nas narrativas que possa revelar a historicidade contida em suas páginas, compreendendo que testemunho, memória coletiva e memória histórica estão intimamente relacionados e seguem tensionando a relação com a história e com a historiografia.

Nesse contexto, é válido retomar aqui, novamente, a importância do regime de verdade adotado pelo jornalismo que ao criar condutas que devem conduzir as narrativas para a imparcialidade e a objetividade, tendo como mote uma vontade de verdade, como também, devem influir na figura do testemunho como elemento da essência do jornalismo e do jornalista, termina contribuindo para apropriações positivas e negativas de si, que ao final é o avalista do jornalismo na sociedade.

Essa proposição de adoção ampliada do testemunho imagético/midiático tem como intuito desvelar os usos que a Rede Globo fez da figura do testemunho para invisibilizar ou tentar silenciar contextos e narrativas históricas, tais como nas Diretas Já $a^{6}$ em 1984, objeto de observação no presente texto, pois como nos diz Burke (2017:277) as imagens oferecem importantes testemunhos sobre o passado e mesmo

\footnotetext{
${ }^{5}$ Em um sentido Foucaultiano composto a partir da vontade de verdade, dos jogos de verdade e das políticas de verdade em cada sociedade (FOUCAULT,1996, 1998,2008,2011,2014,2016)

${ }^{6}$ Objeto deste artigo. Ver nota número 1.
} 
quando, no caso dos historiadores, as imagens reforçam o que eles já intuíam ou sabiam, elas tem algo a acrescentar.

\subsection{O Testemunho, Memória, Anamnese e Esquecimento}

No que concerne ao testemunho na comunicação, sabemos que desde a ascensão do modelo positivista de jornalismo asséptico [que aqui criticamos] e que tem marcado a construção mitológica do estatuto de verdade já mencionado; que o testemunho vem ocupando espaço, cada vez maior, na narrativa jornalística.

De um lado, após os grandes conflitos do século XX abriu-se caminho para os testemunhos nos tribunais políticos, em face das grandes injustiças e dos grandes males sofridos pelas populações perseguidas em diversas partes do planeta; por outro narrativas do sofrimento e da dor como a de Primo Levi testemunha do vivido no campo de concentração Auschwitz, ou, narrativas testemunhais da violência como a de John Reed em Dez dias que abalaram o mundo, se fazem tanto presentes como necessárias para que a cura da sociedade ${ }^{7}$ ocorra pela rememoração do vivido. Essas narrativas testemunhais, assim como, a própria prática de uso do testemunho, se lançam para além de seus espaços de construção e chegam à historiografia e ao jornalismo. Na primeira o dever de memória e o dever de justiça foram conclamados, no segundo a necessidade de credibilizar o discurso se fez maior.

É bem verdade que o jornalismo explora o testemunho de inúmeras maneiras, de um lado, rotiniza o testemunho muitas vezes esvaziando-o, quando não, aproveita a possibilidade do testemunho para expor o outro, eventualmente, de forma antiética; enquanto que em outras situações, reverbera vozes de instituições jurídicas e sociais com a pretensão de se aproximar da verdade.

A Comissão Nacional da Verdade-CNV criada pela Presidenta Dilma Rousseff através da Lei 12.528/2011 tinha como intuito realizar uma revisão inicial da memória nacional sobre os atos cometidos pelo Estado brasileiro ao longo do século XX. Essa comissão, daqui em diante denominada CNV, foi constituída oficialmente em 16 de maio de 2012 com o objetivo de apurar as violações aos Direitos Humanos ocorridos no Brasil entre 1946 e 1988, portanto, extrapolando o período dos Governos militares, embora, situando a maior parte de seus trabalhos entre as décadas de 1960 e 1970, uma vez que nesse período aconteceram os governos mais repressivos e violentos.

\footnotetext{
${ }^{7}$ Conforme Ricoeur (2012) em que a cura da sociedade após eventos trágicos/traumáticos, pode ocorrer quando memória e esquecimento se alinham, na punição ou no perdão e a sociedade passa a limpo seus erros.
} 
A Comissão Nacional da Verdade que concluiu seus trabalhos em dezembro de 2014, teve seu relatos construídos a partir de testemunhos dos envolvidos nos inúmeros casos de perseguidos durante a ditadura civil militar. Os relatos foram reproduzidos pelo jornalismo que muitas vezes se colocava como testemunha do acontecimento atual para se apropriar do valor de verdade da CNV.

No caso da Rede Globo de Televisão a apropriação se deu a partir do esvaziamento de seu próprio passado de apoiadora do regime e de suas tentativas de silenciar os movimentos democráticos no Brasil. Entre 2012 e 2014, período de atuação da CNV, essa empresa chegou a fazer comunicados se colocando como democrática e tentando limpar a imagem coadunada com o regime do passado, mas raras vezes admitiu os erros que cometeu.

Hoje quando os movimentos fascistas no Brasil pedem o retorno da ditadura, ela se mostra mais uma vez conivente com as forças que pretendem retroagir a um governo conservador ou mesmo um regime ditatorial e se utiliza de artifícios, inclusive, da forte figura testemunhal e credível que possui junto à população brasileira para sensibilizar as mentes em favor de suas ideologias.

No contexto em análise, o testemunho é assim uma presença em um evento do passado (praeterita) que se revela no presente através de um discurso de autoreferencialidade. Para Heidegger (2015) o que se deseja do testemunho

[...] é um poder-ser próprio da pre-sença por ela mesma, testemunhado em sua possibilidade existenciária. Antes de tudo é preciso que esse testemunho se deixe encontrar. E caso esse testemunho "se dê a compreender para a pre-sença em sua existência própria e possível, então ele deve ter suas raízes no ser da presença. A demonstração fenomenológica desse testemunho resguarda, pois, a comprovação de sua origem a partir da constituição ontológica da pre-sença [...].

O testemunho deve dar a compreender um poder-ser-si-mesmo, em sentido próprio. Com a expressão "si-mesmo" (N6) chegamos a responder à questão do quem da pre-sença. O si-mesmo da pre-sença foi formalmente determinado como um modo de existir e não como algo simplesmente dado. Na maior parte das vezes, o quem da pre-sença não é eu mesmo, mas o próprio-impessoal (HEIDEGGER, 2015: 52).

Entretanto, como nos chama atenção Ricoeur (2012) o testemunho envolve de um lado a realidade factual passada e ora relatada, como também a necessidade de uma certificação de que há verdade no relato da pessoa que dá o testemunho. Nas palavras do autor

A especificidade do testemunho consiste no fato de que asserção de realidade é inseparável de seu acoplamento com a autodesignação do sujeito que 
testemunha. Desse acoplamento procede a fórmula típica do testemunho: eu estava lá. $\mathrm{O}$ que se atesta é individualmente a realidade da coisa passada e a presença do narrador nos locais da ocorrência. E é a testemunha que no início se declara testemunha. Ela nomeia a si mesma. Um triplo dêitico pontua a autodesignação: a primeira pessoa do singular, o tempo passado do verbo e a menção ao lá em relação ao aqui. Esse caráter auto-referencial é por vezes sublinhado por certos enunciados introdutórios que servem de "prefacio". Esses tipos de asserções ligam o testemunho pontual a toda a história de uma vida. [...]. É por isso que a impressão afetiva de um acontecimento capaz de tocar a testemunha com força de um golpe não coincide necessariamente com a importância que lhe atribui o receptor do testemunho (RICOEUR, 2012:172).

Contudo, não basta se autodesignar como testemunha, mas se exige da testemunha credibilidade, normalmente pautada na situação de presença reforçada por outras presenças que se tornam testemunhas da testemunha.

A autodesignação se inscreve numa troca que instaura uma situação dialogal. É diante de alguém que a testemunha atesta a realidade de uma cena à qual diz ter assistido, eventualmente como ator ou como vítima, mas, no momento do testemunho, na posição de um terceiro com relação a todos os protagonistas da ação. Essa estrutura dialogal do testemunho ressalta de imediato sua dimensão fiduciária: a testemunha pede que Ihe dêem crédito. Ela não se limita a dizer: "Eu estava lá", ela acrescenta: "Acreditem em mim". A autenticação do testemunho só será então completa após a resposta em eco daquele que recebe o testemunho e o aceita: o testemunho, a partir desse instante, está não apenas autenticado, ele está acreditado. É o credenciamento, enquanto processo em curso, que abre a alternativa da qual partimos entre confiança e suspeita. Pode ser mobilizada toda uma lista de argumentos de dúvida, que a psicologia judiciária, evocada no início, alimenta com razões bem ponderadas: essa lista pode referir-se às condições mais comuns para a má percepção, a má retenção, a má reconstituição (RICOEUR, 2012:173).

No contexto jornalístico normalmente não há tempo nem condições para que a apuração se dê de forma aprofundada como o fazem os profissionais da historiografia ou do direito. Aqui pisamos em terreno incerto pelo menos no momento inicial em que nos colocamos também como testemunhas, ou quando nos referenciamos como testemunhas tendo como base o testemunho de outrem.

Todavia, embora estejamos em terreno movediço, na atualidade ainda nos apossamos, enquanto instituição, do lugar de testemunha do atual. Essa situação social do jornalismo o faz procurar dotar o seu discurso de proteção contra toda e qualquer contestação, procurando reforçar o testemunho a qualquer preço, trabalhando a agenda do restante da mídia e do público, ao tempo em que reafirma suas posições. 
Insere-se então uma dimensão suplementar de ordem moral destinada a reforçar a credibilidade e a confiabilidade do testemunho, a saber, a disponibilidade da testemunha de reiterar seu testemunho. A testemunha confiável é aquela que pode manter seu testemunho no tempo. Essa manutenção aproxima o testemunho da promessa, mais precisamente da promessa anterior a todas as promessas, a de manter sua promessa, de manter a palavra. [...]. A testemunha deve ser capaz de responder por suas afirmações diante de quem quer que lhe peça constas dela (RICOEUR, 2012:174).

Entretanto, eventualmente por uma imposição social, os meios de comunicação podem vir a negar seus próprios testemunhos e até posturas do passado. Evidências nesse sentido podem ser apuradas nas falas dos grupos jornalísticos brasileiros ao longo dos últimos anos e concernentes a suas posturas e práticas durante a ditadura civil-militar.

O testemunho confere a condição de presença do jornalismo e o insere em sua temporalidade, atestando sua historicidade, que posteriormente, pode vir a ser temporalizada.

E é exatamente a função de testemunha da sociedade que confere ao jornalismo a possibilidade de ser o lugar de uma certa memória social e coletiva, de ser um dos grandes componentes e influenciadores da construção da memória histórica, tendo ainda grande responsabilidade sobre o rio de Lethe $^{8}$ que relega ao esquecimento 0 que não se quer que seja conhecido ou lembrado pelas sociedades. O testemunho do jornalismo fala do outro a que se refere, mas é também uma fala de si, que carrega os traços de sua própria temporalidade e modelos. É bem verdade que as duas vertentes carregam complicadas relações com a realidade, relações essas que se formulam entre as inquietações calcadas na ordem do dito e do não dito.

Em 2015 e 2016 tivemos no Brasil inúmeras manifestações em que parte do povo brasileiro saiu às ruas para pedir o impeachment da Presidenta Dilma Rousseff e ao mesmo tempo manifestar desejos como, por exemplo, o retorno da ditadura civilmilitar sob a alegação de que naquele período não havia corrupção, nem tampouco violência. A fala mais recorrente entre os brasileiros que reclamam o retorno ao tempo dos militares, é de que "na ditadura militar não se ouvia falar em corrupção", de fato não se ouvia falar porque não se podia falar, a espiral do silêncio se completava na orquestração midiática ora imposta, ora voluntária. Por outro lado, é válido destacar que durante o regime civil-militar não existiam Instituições públicas de acompanhamento, transparência e apuração de ilícitos nos atos do governo, como as que foram criadas ou fortalecidas nos governos do Partido dos Trabalhadores.

\footnotetext{
${ }^{8}$ Rio do esquecimento, um dos cinco rios através dos quais, os mortos podem chegar até o mundo inferior.
} 
Logo esse lugar de testemunha do presente e, portanto de profissionais de uma certa memória que ocupa o jornalismo (LE GOFF, 2003) é o que o faz ser detentor de uma certa historicidade intermitente e situada entre a comunicação e a história.

No campo midiático, tanto nos auto referenciamos como testemunhas por excelência do presente; como nos situamos como construtores permanentes da memória e recorremos com efetiva frequência à prática da anamnese, para reforçamos no presente as falas de um presente no passado. Esse recordar pela reminiscência se coloca discursivamente como natural e simples, normalmente mascarando os vestígios de um interesse no passado. Como afirma Voegelin (2009), anamnese é um resgate muito mais do presente do que do passado. Trata-se de um fala que se coloca disponível diacronicamente e que pode ser acessada recorrentemente quando necessária pelo interlocutor para reforço discursivo. Para este autor,

[...]O que é provocado não é uma volta do passado, mas uma consciência ampliada do que já está presente como a possiblidade do próprio encontro. [...]. Tudo o que temos é anamnese obtida historicamente, nossos próprios esforços meditativos pessoais e o fruto do esforço colaborativo ao longo das gerações. 0 movimento meditativo não pode acontecer dentro de um vácuo. Tem de ser constituído através da luta para trazer as questões de onde começa a se articular a consciência e não há nenhum depósito de formas simbólicas, exceto aquelas que emergiram historicamente (VOEGELIN, 2009: 26).

Esse movimento de anamnese jornalística pode ser visualizado através das retrospectivas que ligam acontecimentos marcantes do passado a outros similares no presente, ou nos dossiês sobre temas abordados politicamente. Testemunhos de uma presença reclamados pelo próprio jornalismo e não somente pela história.

Todavia, na cobertura das Diretas Já que aqui analisaremos, os recursos de testemunho e sua relação intrínseca com a construção da memória coletiva em um presente do passado, foram utilizados com a intencionalidade de suprimir a realidade e os anseios democráticos do povo brasileiro. Naquela época tanto quanto hoje, quando o Brasil encontra-se dividido, a Rede Globo de Televisão trabalha para eventualmente para silenciar os movimentos que se levantam contra os seus interesses. A primavera das \#mulheresunidascontrabolsonaro ${ }^{9}$, como dito anteriormente, reuniu 4 milhões de mulheres em um grupo no Facebook e levou milhões e milhões às ruas de todo o Brasil e de várias cidades do mundo e foi silenciada até o último momento, somente sendo noticiada quando não dava mais para esconder, mesmo assim, sem nenhum destaque no noticiário da emissora, divergindo de sua cobertura de 24 horas nas campanhas pelo impeachment da

\footnotetext{
${ }^{9}$ Movimento que reuniu milhões de mulheres e homens contra o candidato à presidência do Brasil, Jair Bolsonaro, em manifestações no dia 29 de setembro de 2018.
} 
Presidenta Dilma Rousseff nos anos anteriores, mas esses temas não compõem esta pesquisa e não nos aprofundaremos neles.

No caso do movimento Diretas Já realizado na década de 1980 o modus operandi da Rede Globo de Televisão foi claro no sentido de operar em prol do esquecimento, utilizando-se contraditoriamente, da própria figura do testemunho auto-referencial para soterrar camadas da realidade no rio do esquecimento.

Vale pensar que foram ações nesse sentido que ocasionaram a negligência do Brasil com a própria memória, que por não ter tido um tratamento social devido, a partir de um reconhecimento dos erros do Estado visto que a Lei da Anistia soterrou a dor e a violência, impondo às vítimas e aos algozes o mesmo falso perdão, nem tampouco, ter sido tratada como uma memória exemplar no sentido atribuído por Todorov (2008), terminou se transformando numa ponte para leituras históricas tensionadas e disputadas entre parte da sociedade que defende os militares e parte que entende 0 trauma ocasionado pelo regime ditatorial. História e memória da ditadura civil-militar continuam em disputa no Brasil.

O testemunho foi recorrentemente utilizado pelos meios de comunicação para referendar seus pontos de vistas, a partir de ângulos distintos que objetivavam o esquecimento.

Para Ricoeur as ideologias se aproveitam das fragilidades identitárias das sociedades para manipular a memória histórica, a partir de gestos de memória que negligenciam o passado vivido em prol de versões construídas, em suas palavras

[...] tudo o que constitui a fragilidade da identidade se revela assim oportunidade de manipulação da memória, principalmente por via ideológica. Por que os abusos da memória são de saída abusos do esquecimento? Nossa explicação então, foi: por causa da função mediadora da narrativa, os abusos de memória tornam-se abusos de esquecimento. De fato, antes de abuso, há o uso, a saber, o caráter inelutavelmente seletivo da narrativa. A ideia de narração exaustiva é uma ideia perfomativamente impossível. A narrativa comporta necessariamente uma dimensão seletiva. Alcançamos, aqui, a relação estreita entre memória declarativa, narratividade, testemunho, representação figuração do passado histórico (RICOEUR, 2012: 455).

Sabemos que tanto a memória quanto a história (enquanto campo do vivido) se constrói no presente de vivência e experiência. Quando, portanto, no presente se trabalha pelo esquecimento, pelo apagamento, trabalha-se pela manipulação direta da memória coletiva cuja reflexividade será visível na memória histórica e na historiografia disputada. Como nos lembra Ricoeur (idem) “[...] as estratégias do esquecimento enxertam-se diretamente nesse trabalho de configuração: pode-se sempre narrar de outro modo, suprimindo, deslocando as ênfases, refigurando 
diferentemente os protagonistas da ação assim como os contornos dela". Portanto, a narrativa enredada pode se tornar uma "armadilha" quando a composição da intriga é direcionada em um caminho distinto que pode se dar tanto pela imposição como pela sedução.

Está em ação aqui uma forma ardilosa de esquecimento, resultante do desapossamento dos atores sociais de seu poder originário de narrarem a si mesmos. Mas esse desapossamento não existe sem uma cumplicidade secreta, que faz do esquecimento um comportamento semipassivo e semi-ativo, como se vê no esquecimento de fuga, expressão da má-fé, e sua estratégia de evitação motivada por uma obscura vontade de não se informar, de não investigar o mal cometido pelo meio que cerca o cidadão, em suma por um querer-não-saber (RICOEUR, ibidem).

Percebemos aqui que o testemunho pode tanto servir a memória, quanto ao esquecimento e é nesse sentido que procuramos interpretar as narrativas da Rede Globo de Televisão concernentes ao movimento das Diretas Já na década de 1980.

\section{A cobertura da Rede Globo e a tentativa de esquecimento}

Em um Brasil mergulhado em um governo ditatorial por duas mais de duas décadas, inúmeros fatores e variáveis intermitentes confluíram para o deflagrar de um movimento em prol da redemocratização do país. Diferentemente de outros países da América Latina, no Brasil o fim do regime civil-militar não se deu através de um levante popular, mas de negociações entre os que ocupavam os cargos no aparelho do poder.

A crise econômica mundial deflagrada ainda na década de 1970 com a crise do petróleo, terminou por suprimir o milagre econômico da era Médici no Brasil e aprofundou o abismo social, refletindo diretamente no comando do país. Nesse período os militares se dividiam em alas opositoras e a partir de pressões populares foram obrigados a aderir a um processo progressivo de redemocratização. A ideologia anticomunista que se fizera presente nas propagandas do Instituto de Pesquisas Sociais-IPES, grande articulador do golpe de 1964, se afasta para dar lugar às reivindicações de um país livre e que deseja novamente um crescimento econômico. No entanto, as negociações que visavam a democratização foram benéficas aos militares e seus apoiadores. No caso da Lei da Anistia de 1979 temos uma lei que trabalha em prol do esquecimento. Como afirma Ricoeur (2012) essa correspondência 
acontece, sobretudo, quando formas institucionais de esquecimento se estabelecem, a exemplo da anistia que trabalha em linha tênue com a amnésia.

Mas a anistia, enquanto esquecimento institucional, toca nas próprias raízes do político e, através deste, na relação mais profunda e mais dissimulada com um passado declarado proibido. A proximidade mais que fonética, e até mesmo semântica, entre anistia e amnésia aponta para a existência de um pacto secreto com a denegação de memória que, como veremos mais adiante, na verdade a afasta do perdão após ter proposto sua simulação (RICOEUR, 2012:460).

Vale pensar que essas negociações extrapolaram a anistia, visto que visou ainda conservar os benefícios e o status quo da maioria dos políticos que atuavam no regime civil-ditatorial e que no processo democrático, continuaram atuando como se nada tivesse acontecido no país. Nesse sentido é que as negociações no Congresso primaram pela manutenção do controle político e pela contenção das manifestações populares que eclodiram em 1984.

Todavia, mesmo com a restrição do acesso de novos personagens na cena política brasileira no início da década de 1980, nem mesmo a repressão das manifestações populares viria a se interpor a abertura política e ao renascimento dos movimentos sociais que retornam com grande força e que irão se posicionar no cenário nacional como atores de transformação em tempos de redemocratização. Nesse sentido é que um olhar para esse presente do passado, nos permite reconhecer que a redemocratização se deu ao mesmo tempo em que a sociedade civil se reconstituiu como tal e com toda força.

Como afirmam Teixeira e Chaves (2004) a redemocratização e o movimento das Diretas Já situaram em seu contorno atores de um regime que se transmutava, mas objetivava permanecer no poder, como também cidadãos que novamente ganhavam as ruas lutando pelo direito ao voto e a voz no cenário nacional. A sociedade se reestruturou enquanto organismo vivo de reivindicações e luta. Motivada pela Proposta de Emenda Constitucional Dante de Oliveira, partidos políticos organizados e que desejam permanecer na nova ordem, organizações sindicais, artistas, jogadores de futebol, cidadãos comuns formaram uma voz uníssona em torno da proclamação das eleições diretas.

O movimento das Diretas Já passou para os anais da história como o momento em que o povo brasileiro se uniu em prol da liberdade e com o desejo de mudança, tendo em vista, principalmente, a grande crise econômica em que o país estava mergulhado. Os espaços públicos foram ocupados pelo povo enquanto sujeito político coletivo que exigia ação e tornava-se consciente da necessidade de luta.

As grandes concentrações de pessoas em comícios nas grandes cidades brasileiras tornaram-se comuns e que pautadas pelo movimento ganhavam força a cada dia. 
Eram manifestações de força do desejo do povo cuja consciência política estava aflorada novamente. Para Sader as "[...] movimentações que antes podiam ocorrer de modo quase silencioso [...] passam a ser valorizadas enquanto sinais de resistência, vinculadas a outras num conjunto que lhes dá a dignidade de um acontecimento histórico (SADER, 1988: 12).

Foi nesse contexto de grande efervescência popular no movimento das Diretas Já que o comício da Praça da Sé em São Paulo foi realizado no dia do aniversário da cidade, 25 de janeiro de 1984. Alguns dias antes, outro ato político realizado em Curitiba (PR) com a mesma finalidade, foi completamente ignorado pela emissora. Nessa época já aconteciam atos pelas diretas em várias cidades brasileira.

Segundo a própria Globo ${ }^{10}$ após o comício de Curitiba a emissora passou a cobrir os atos convocados pelo movimento pelas Diretas Já. No dia 25 de janeiro o Jornal Nacional ${ }^{11}$ cujo âncora era o jornalista Marcos Hummel anunciou o evento das Diretas Já, tão somente como um dos 500 eventos que se realizaram no dia em que São Paulo comemorava seus 430 anos.

A matéria sobre o aniversário da cidade começa com o jornalista Ernesto Paglia falando do aniversário da cidade em off em cima de imagens da cidade. Confira a transcrição do áudio da matéria que teve um pouco menos de 3 minutos de duração.

Marcus Hummel (âncora): "Um dia de festa em São Paulo. A cidade comemorou seus 430 anos com mais de 500 solenidades. A maior foi um comício na Praça da Sé".

Ernesto Paglia (jornalista): "São Paulo completou 430 anos, 9 milhões de brasileiros vindos de todo o país. Cidade de trabalho, São Paulo fez feriado hoje para comemorar o aniversário que é também o aniversário de seu templo mais importante, a Catedral da Sé. De manhã, na missa o Cardeal Arcebispo Dom Evaristo Arns lembrou o importante papel da Catedral da Sé nesses 30 anos em que ela vive no coração da cidade.

Dom Evaristo Arns (arcebispo): "a Igreja se promoveu como povo que quer manifestar-se como povo. Eu acho que isso é fundamental para uma Igreja mãe que é tratada com tanto carinho".

\footnotetext{
${ }^{10}$ http://memoriaglobo.globo.com/erros/diretas-ja.htm

11 Principal telejornal da Rede Globo de Televisão, está no ar há mais de 50 anos, sendo ainda hoje o jornal televisivo mais assistido do país. É importante salientar ainda, que a televisão é ainda hoje, a principal fonte de informação da população brasileira conforme pesquisas do Instituto Brasileiro de Geografia e Estatística-IBGE 2014 (http://www.brasil.gov.br/governo/2014/12/televisao-ainda-e-omeio-de-comunicacao-predominante-entre-os-brasileiros) e $\quad$ IBGE 2016 https://g1.globo.com/economia/midia-e-marketing/noticia/tv-e-o-meio-preferido-por-63-dosbrasileiros-para-se-informar-e-internet-por-26-diz-pesquisa.ghtml ).
} 
Ernesto Paglia (jornalista): e junto com a cidade aniversariou também a Universidade de São Paulo. A USP completou 50 anos de existência. A Ministra da Educação, Esther Figueiredo Ferraz foi a USP hoje. Ela falou da importância da universidade com suas 33 faculdades e seus 45 mil alunos e assistiu a uma inesperada manifestação de estudantes e funcionários. Eles tomaram o anfiteatro com faixas e cartazes e pediram verbas para a educação e eleições diretas para reitor e para presidente da república.

Mais tarde milhares de pessoas vieram ao centro de São Paulo se reunir em um comício que pedia eleições diretas para presidente. Não foi apenas uma manifestação política. Na abertura música. Um frevo do cantor Moraes Moreira. A praça da Sé e todas as ruas vizinhas estão lotadas. No palanque mais de 400 pessoas, deputados, prefeitos e muitos artistas. Cristiane Torloni, Regina Duarte, Irene Ravache, Chico Buarque, Milton Gonçalves, Esther Goes, Bruna Lombardi, Alceu Valença, Fernanda Montenegro, Gilberto Gil. A chuva não afasta o povo. Os oradores se sucedem no palanque e ninguém arreda o pé. O radialista Osmar Santos apresenta os oradores. O governador de São Paulo, Franco Montoro fez o discurso de encerramento.

Considerando com Ricoeur (2012) que a narrativa carrega em si uma dimensão seletiva e que a relação desta com a memória declarativa é patente e atrelada ao testemunho, interpretando os caminhos e as escolhas da narrativa da emissora Globo quando da matéria que cobriu o comício de 25 de janeiro de 1984, percebemos que alguns pontos são carregados de potência para o esquecimento, muito mais do que para a memória do acontecimento.

Em primeiro lugar toda a matéria gira em torno do aniversário da cidade e não do acontecimento popular de proporções gigantescas para um período ditatorial, como o que ainda se vivia no Brasil então. Em segundo lugar, a chamada do âncora, Marcos Hummel reduz o evento e dilui a importância do evento em meio a mais 500 solenidades que aconteceram na cidade no mesmo dia. Em terceiro lugar, outros pontos são chamados para tirar a atenção da importância política e popular daquele evento. A cobertura do aniversário da Catedral da Sé, quando no entanto, a voz do Cardeal lembra que o povo deseja manifestar-se. O aniversário da USP cuja cobertura tem o foco na Ministra da Educação, entretanto, um evento dentro do evento, traz o foco novamente para o momento político estudantes e funcionários se manifestam pelas eleições diretas também. E, por último, a tentativa do repórter que cobria o evento, Ernestro Paglia, de minimizar a importância do evento, quando afirma não se tratar somente de uma manifestação política.

O testemunho do jornalista acoplado ao testemunho da emissora objetiva dar outra conotação ao ato político que deflagrou um movimento de grandes proporções e que a Globo foi obrigada a cobrir nos vários cantos do país. 
Hoje em sua página Memória Globo (http://memoriaglobo.globo.com/erros/diretasja.htm) existe uma seção sobre a cobertura das Diretas Já onde localizamos uma pequena nota com o reconhecimento do erro, mas com a afirmação de que não foi proposital. O erramos ${ }^{12}$ quase não é perceptível:

A origem da confusão foi a chamada da matéria, lida pelo apresentador Marcos Hummel, que se referia ao comício da Sé como um dos eventos comemorativos do aniversário da cidade. O locutor leu a chamada: "Festa em São Paulo. A cidade comemorou seus 430 anos com mais de 500 solenidades. A maior foi um comício na Praça da Sé. De fato, havia a relação entre a manifestação e o aniversário da cidade. Os organizadores haviam marcado o evento para o dia 25 de janeiro justamente para facilitar a participação popular. E, se a chamada da matéria parecia não levar em consideração a dimensão política do comício, em seguida, a reportagem de Ernesto Paglia relatou com todas as letras o seu objetivo: pedir eleições diretas para presidente da República (MEMÓRIA GLOBO, Diretas Já).

Novamente a Globo se utiliza da figura do testemunho auto-referencial para estabelecer e reforçar os laços de credibilidade junto a seu público. Dessa vez o interesse não é o silenciamento do movimento, mas afirmar o contrário, que nunca tentou silenciar o movimento das Diretas Já, o testemunho aqui (da matéria do Ernesto Paglia) conflita com o testemunho do Marcos Hummel, com o objetivo de reconhecer um erro, porém não intencional e pequeno.

Todavia, como vimos as escolhas para a matéria levam a uma interpretação que desvela as tentativas de silenciamento a partir dos testemunhos e das coberturas dos demais eventos do aniversário da cidade. A matéria sobre o aniversário poderia ter coberto todos os 500 eventos, mas pelos critérios de noticiabilidade, o comício da Praça da Sé merecia um grande destaque ou uma matéria jornalística exclusiva. A negação do evento acontece dentro da própria cobertura, como visto, quando o repórter nega tratar-se de um movimento político.

\section{Conclusões}

Em 21 abril de 2015, no segundo capítulo da série de comemorações dos 50 anos de jornalismo da Rede Globo, William Bonner, atual âncora do Jornal Nacional, relembrou

12 No Brasil denominamos de ERRAMOS os textos jornalísticos em que os veículos de comunicação reconhecem publicamente os erros cometidos em reportagens, notícias publicadas, etc. Quando fruto de ação judicial o texto passa ser de reparação por algum dano causado à imagem e reputação de alguém/alguma instituição; nesse caso, o prejudicado terá um direito de resposta no mesmo espaço jornalístico e com o mesmo tempo que a matéria que o difamou. 
a reportagem de 25 de janeiro de 1984 e reconheceu o erro na abordagem adotada pela emissora.

Essa reportagem provocou muita polêmica ao longo de muitos anos porque, embora ela falasse do comício das Diretas, o texto que introduzia a reportagem, lido pelo apresentador na época, não falava em comício das Diretas[...] Isso foi visto por muitos anos como uma tentativa da Globo de esconder as Diretas e, obviamente, depois de muitos anos também, foi reconhecido como erro (WILLIAM BONNER, Jornal Nacional, 21 abril de 2015).

Memória e esquecimento andam lado a lado e são alvo de disputas de poder no seio das sociedades. Como nos diz Le Goff (2003: 470) a "[...] memória, na qual cresce a história, que por sua vez a alimenta, procura salvar o passado para servir ao presente e ao futuro. Devemos pois, trabalhar de forma que a memória coletiva sirva para a libertação e não para a servidão dos homens". Todavia, quando um meio de comunicação de grande audiência, reputação e "referência" no meio social comete equívocos ou atos intencionais que procuram mudar os rumos dos acontecimentos, procurando através do próprio testemunho em que dizem: acreditem em mim, o que está ocorrendo é isto e não o que vocês estão vendo!_os riscos de rasgos no tecido histórico são bem maiores. Talvez por isso, o capítulo da ditadura civil-militar no Brasil não esteja resolvido, visto que as forças da extrema direita desejam realizar um revisionismo manipulatório da memória e da historiografia.

A falta de memória, como nos diz Ricoeur (2012) pode ser classificada como uma forma de esquecimento passiva uma vez que equivale a falta de trabalho da memória coletiva. Sempre que a mídia enquanto lugar de memória_ citando Nora (2008) quando este ao final dos volumes da coleção Lugares de Memória, abre o conceito para o encontro entre o passado e o presente a partir do sistema de signos_esvai-se da sua função e intencionalidade contributiva da memória coletiva e histórica e atua em outra direção, dentro das tensões sociais e políticas das quais participa, a memória social fica ameaçada e com ela a história, e ambas caminham para o esquecimento.

Mas, enquanto estratégia de evitação, de esquiva, de fuga, trata-se de uma forma ambígua, ativa tanto quanto passiva, de esquecimento. Enquanto ativo, esse esquecimento acarreta o mesmo tipo de responsabilidade que é imputada aos atos de negligência, de omissão, de imprudência, de imprevidência, em todas as situações do não-agir, nas quais, posteriormente, uma consciência esclarecida e honesta reconhece que se devia e se podia saber ou pelo menos buscar saber, que se devia e se podia intervir. Reencontra-se assim, no caminho da reconquista pelos agentes sociais do domínio de sua capacidade de fazer narrativa, todos os obstáculos ligados ao dessabendo das formas de socorro que a memória de cada um pode encontrar na dos outros enquanto capazes de autorizar, de ajudar a 
fazer a narrativa de modo ao mesmo tempo inteligível, aceitável e responsável. Mas a responsabilidade da cegueira recai sobre cada um (RICOUER, 2012: 456).

O exemplo aqui analisado é somente um dos casos em que tanto a Rede Globo de Televisão no Brasil, como inúmeros outros meios de comunicação incorrem na construção de narrativas distorcidas sobre acontecimentos reais. Não constituem fake News, mas se distanciam da realidade trabalhando mais a favor do esquecimento do que da memória ou da história. O uso do testemunho direto através da presença da emissora no local do evento é tão somente um recurso retórico para atestar a sua credibilidade frente a uma narrativa que potencialmente se distingue do fato.

$\mathrm{Na}$ atualidade os veículos jornalísticos do conglomerado Globo continuam se utilizando de estratégias discursivas similares. Nos eventos aqui já mencionados como o impeachment da Presidenta Dilma Rousseff em 2016, quanto no processo eleitoral de 2018 é perceptível em inúmeros momentos, estratégias de visibilidade de fatos construídos que desviam a atenção do público, para acontecimentos importantes, que ao final se tornam silenciados, todavia, essa será uma nova pesquisa.

\section{Referências bibliográficas}

BURKE, Peter (2017). Testemunha ocular: o uso de imagens como evidência histórica. São Paulo: Editora Unesp.

BARBOSA, Marialva (2006). O filósofo do Sentido e a Comunicação. In: Conexão Comunicação e Cultura, UCS, Caxias do Sul, v. 5, n. 9, p. 139-149, jan./jun.

FOUCAULT, Michel (1995). A Arqueologia do saber. Rio de Janeiro: Forense.

FOUCAULT, Michel (2008). Ditos \& escritos II: arqueologia das Ciências e história dos sistemas de pensamento. Rio de Janeiro: Forense Universitária.

FOUCAULT, Michel (2011). A coragem de verdade. São Paulo: Ed. Martins Fontes.

FOUCAULT, Michel (2014). Vigiar e punir. Petrópolis: Vozes.

FOUCAULT, Michel (2016). L'ordre du discours. Paris: Gallimard.

HARTOG, François (2015). Regimes de historicidade: presentismo e experiências do tempo. Belo Horizonte: Autêntica.

HEIDEGGER, Martin (2015). Ser e Tempo. Petrópolis: Vozes. 
LEAL, Bruno Souza (2014). Quando uma notícia é parte da história: as mídias informativas e a identidade narrativa. In: E-compós, Brasília, v.17, n.3, set./dez.

LE GOFF, Jacques (2003). História e Memória. Campinas: Ed. UNICAMP.

NIETZSCHE, Friedrich (2005). Além do bem e do mal. São Paulo: Companhia das Letras.

NORA, Pierre (2008). Les lieux de mémoire. Montevideo: Trilce.

RICOEUR, Paul (2012). A memória, a história, o esquecimento. Campinas: Ed. Unicamp.

RICOEUR, Paul (2010). Tempo e Narrativa. V.1,2,3. São Paulo: Ed. WMF Martins Fontes.

SADER, Eder (1988). Quando novos personagens entram em cena. Experiências e lutas de trabalhadores da grande São Paulo 1970 - 1980. Rio de Janeiro: Paz e Terra.

TEIXEIRA, Carla Costa; CHAVES, Christine de Alencar (Orgs.) (2004). Espaços e Tempos da Política. Rio de Janeiro: Relume Dumará, Núcleo de Antropologia da Política/UFRJ.

TODOROV, Tezvetan (2008). Los abusos de la memória. Barcelona: Paidós.

VOEGELIN. Eric (2009). Anamnese: da teoria da História e da Política. São Paulo: Realizações Editora. 